DOI: $10.15193 /$ zntj/2020/124/343

\author{
DOROTA ZIELIŃSKA, DANUTA KOŁOŻYN-KRAJEWSKA
}

\title{
ZMIANY NOMENKLATURY TAKSONOMICZNEJ WAŻNYCH GATUNKÓW PROBIOTYCZNYCH BAKTERII LACTOBACILLUS
}

\begin{abstract}
Streszczenie
Gatunki Lactobacillus mają ogromne znaczenie w życiu człowieka, począwszy od ich kluczowej roli w fermentacji żywności, a skończywszy na korzystnym dla zdrowia wpływie na organizmy ludzi i zwierząt. Celem niniejszej pracy było przedstawienie, z uwzględnieniem historii rodzaju Lactobacillus, obecnej rewolucyjnej zmiany nomenklatury taksonomicznej, a także przedyskutowanie znaczenia tej zmiany dla konsumentów, producentów żywności probiotycznej i innych zainteresowanych stron. Piętnastu naukowców z dwunastu różnych instytucji i siedmiu różnych krajów przeanalizowało cały genom każdego znanego gatunku Lactobacillus i wskazało propozycję zmian. Propozycja ta została przyjęta do druku w oficjalnym dzienniku rejestrów nazw bakterii. W analizie autorzy przyjęli wielofazowe podejście i na tej podstawie dokonali reklasyfikacji rodzaju Lactobacillus na 25 rodzajów. Ta bezprecedensowa skala zmian może być myląca dla zainteresowanych stron. Jednakże wprowadza także szereg korzyści związanych ze zgrupowaniem blisko spokrewnionych bakterii w bardziej jednolite i stabilne ewolucyjnie taksony, a także ze stworzeniem możliwości lepszego projektowania ukierunkowanych grup żywności, cechujących się funkcjonalnością i biologiczną skutecznością.
\end{abstract}

Słowa kluczowe: Lactobacillus, probiotyki, taksonomia, rodzaj

\section{Wprowadzenie}

Pierwszy gatunek Lactobacillus - Lactobacillus delbrueckii nazwał w 1901 r. Beijerinck, a następnie badacze zajmujący się taksonomią przypisywali do tego rodzaju wiele innych podobnych bakterii, które izolowano z różnych źródeł. Do rodzaju Lactobacillus zalicza się mikroorganizmy Gram-dodatnie, fakultatywnie beztlenowe i niewytwarzające przetrwalników. Rodzaj ten należy do typu Firmicutes, klasy Bacilli, rzędu Lactobacillales, rodziny Lactobacillaceae, która obejmuje rodzaje Lactobacil-

Dr hab. D. Zielińska, prof. SGGW, prof. dr hab. D. Kołożyn-Krajewska, Katedra Technologii Gastronomicznej i Higieny Żywności, Instytut Nauk o Żywieniu Człowieka, Szkoła Główna Gospodarstwa Wiejskiego w Warszawie, ul. Nowoursynowska 159 C, 02-776 Warszawa.

Kontakt:dorota_zielinska@sggw.edu.pl; danuta_kolozyn_krajewska@sggw.edu.pl 
lus, Paralactobacillus i Pediococcus [13]. Do marca 2020 r. rodzaj Lactobacillus obejmował 261 formalnie uznanych gatunków [22].

Gatunki Lactobacillus mają ogromne znaczenie w życiu człowieka, począwszy od ich kluczowej roli w fermentacji żywności, a skończywszy na korzystnym dla zdrowia wpływie na organizmy ludzi i zwierząt. Lloyd w książce What on Earth Evolved? [15] wymienił rodzaj Lactobacillus jako piątą najważniejszą kategorię żywych organizmów, które wpłynęły na planetę w całej jej ewolucyjnej historii. Zdolność do fermentacji surowców, tj. mleka, mięsa i roślin wpłynęły na ich skuteczne wykorzystanie w domowej, rzemieślniczej i przemysłowej produkcji żywności, przede wszystkim w celach konserwujących. W związku z tym wiele gatunków Lactobacillus ma długą historię bezpiecznego stosowania przez ludzi. Agencja ds. Żywności i Leków (FDA) w USA uznała je za ogólnie bezpieczne, przyznając im status GRAS, natomiast Europejski Urząd ds. Bezpieczeństwa Żywności (EFSA) uznał ich domniemane bezpieczeństwo. Większość bakterii znajdujących się na liście QPS stanowi naturalną mikrobiotę organizmu człowieka, z czego wynika owo „domniemane” bezpieczeństwo. Europejski sposób kwalifikacji QPS został zainspirowany koncepcją GRAS, którą stosuje się w USA, jednak GRAS jest objęty statusem prawnym, w przeciwieństwie do QPS [23].

Niektóre szczepy są uznawane także za probiotyki, co oznacza, że mogą szczególnie korzystnie oddziaływać na zdrowie człowieka - to stanowi wartość dodaną, poza podstawową wartością odżywczą. Produkty zawierające pałeczki fermentacji mlekowej dominują na światowym rynku probiotyków. Według Markets and Markets [8] rynek probiotyków składa się w dużej mierze z bakterii Lactobacillus i prognozuje się, że do 2023 r. osiągnie wartość 70 mld dolarów.

Rosnący popyt na szczepy probiotyczne spowodował potrzebę izolacji i identyfikacji nowych bakterii. Na przestrzeni lat badacze, którzy odkrywali nowe bakterie, grupowali wiele różnych gatunków pod wspólnym rodzajem Lactobacillus, co spowodowało narastające problemy z porządkiem taksonomicznym.

Celem niniejszej pracy było przedstawienie, z uwzględnieniem historii rodzaju Lactobacillus, obecnej rewolucyjnej zmiany nomenklatury taksonomicznej, a także przedyskutowanie znaczenia tej zmiany dla konsumentów, producentów żywności probiotycznej i innych zainteresowanych stron.

\section{Przynależność taksonomiczna Lactobacillus}

Od kilkudziesięciu lat narastał problem z przynależnością taksonomiczną Lactobacillus. Pierwotnie taksonomia pałeczek kwasu mlekowego bazowała na cechach fenotypowych obejmujących optymalną temperaturę wzrostu, wykorzystanie sacharydów i profil produkowanych metabolitów [3]. Rezultatem tej klasyfikacji jest popularny podział bakterii na homofermentatywne, fakultatywnie heterofermentatywne lub 
obligatoryjnie heterofermentatywne. Wraz z rozwojem technik biologii molekularnej do określenia nowych gatunków bakterii wykorzystywano kryteria genotypowe i chemotaksonomiczne, w tym hybrydyzację DNA - DNA, zawartość zasad azotowych G + C (guanina + cytozyna) w łańcuchu DNA oraz strukturę chemiczną peptydoglikanu. Od 1983 r. w taksonomii bakterii powszechnie wykorzystuje się podobieństwo genów 16S rRNA [2]. Wprowadzenie analizy sekwencji genów 16S rRNA pozwoliło na opracowanie bardziej rozbudowanej taksonomii dla tego rodzaju, ale niestety ujawniło niewielką korelację między tradycyjną klasyfikacją uwzględniającą fenotyp a pokrewieństwem filogenetycznym. Ponadto obszerny opis gatunków „novel” Lactobacillus doprowadził do rozpoznania rosnącej liczby zmiennych podgrup filogenetycznych [5, $13,17]$.

W ciągu ostatnich 15 lat sekwencjonowanie całych genomów bakterii stało się szeroko dostępne. Wskaźnik średnich wartości identyczności nukleotydów (ANI - ang. average nucleotide identity) stał się ,złotym standardem” w porównywaniu parami sekwencji homologicznych genomów bakterii między sobą. Przyjęto, że wartość ANI wynosząca $>95 \%$ predysponuje do zaklasyfikowania bakterii do tego samego gatunku [11]. Salvetti i wsp. [16] oraz Sun i wsp. [19] przeprowadzili badania genetyczne rodzaju Lactobacillus i doszli do przekonania, że wiele gatunków jest zbyt luźno spokrewnionych ze sobą, a wskaźniki podobieństwa genetycznego są zbyt niskie. Dowiedziono również, że przedstawiciele innych rodzajów, takich jak Pediococcus oraz członkowie rodziny Leuconostocaceae (Convivina, Fructobacillus, Leuconostoc, Oenococcus i Weissella) są wymieszani z gatunkami z rodzaju Lactobacillus, co oczywiście stanowi naruszenie wymogu monofiletycznego.

Wśród badaczy narastało przekonanie, że rodzaj Lactobacillus jest zbyt zróżnicowany i niezgodny z konwencjami nazewnictwa. Co więcej, istotne stało się podzielenie rodzaju na grupy, które mają wspólne pewne właściwości fizjologiczne, metaboliczne i warunki życia. Zabieg ten powinien ułatwić badania bakterii $\mathrm{z}$ tego rodzaju, a także wprowadzić poprawną klasyfikację rodzaju bazującą na różnicach w genomie $[14,16,21]$. W celu rozwiązania tego problemu 15 naukowców (tab. 1) z 12 różnych instytucji i 7 różnych krajów przeanalizowało cały genom każdego gatunku Lactobacillus. Ich propozycja została przyjęta do publikacji w oficjalnym dzienniku rejestrów nazw bakterii (International Journal of Systematic and Evolutionary Microbiology, 15 kwietnia 2020 r.). W analizie autorzy przyjęli wielofazowe podejście i na tej podstawie dokonali reklasyfikacji rodzaju Lactobacillus na 25 rodzajów, w tym zmieniony rodzaj Lactobacillus, który obejmuje organizmy przystosowane do żywiciela, określane jako grupa L. delbrueckii; Paralactobacillus. Wprowadzono 23 nowe rodzaje: Acetilactobacillus, Agrilactobacillus, Amylolactobacillus, Apilactobacillus, Bombilactobacillus, Companilactobacillus, Dellaglioa, Fructilactobacillus, Furfurilactobacillus, Holzapfelia, Lacticaseibacillus, Lactiplantibacillus, Lapidilactobacillus, Latilactobacillus, Len- 
tilactobacillus, Levilactobacillus, Ligilactobacillus, Limosilactobacillus, Liquorilactobacillus, Loigolactobacilus, Paucilactobacillus, Schleiferilactobacillus i Secundilactobacillus [22].

Niektóre nazwy rodzajów się zmieniły, jednak część nazw wskazujących na gatunki nie uległa zmianie. W tab. 2. przedstawiono kilka przykładów zmian nazw ważnych probiotycznych pałeczek fermentacji mlekowej. Należy podkreślić, że wszystkie nowe rodzaje proponowane dla tej grupy zaczynają się na literę „L”, więc nadal można używać skrótu rodzaju „L.”.

Tabela 1. Grupy badawcze zaangażowane w zbadanie genomu bakterii z rodzaju Lactobacillus Table 1. Research groups involved in studying genome of Lactobacillus bacteria

\begin{tabular}{|c|c|}
\hline 1. & $\begin{array}{l}\text { Jinshui Zheng, State Key Laboratory of Agricultural Microbiology, Hubei Key Laboratory of } \\
\text { Agricultural Bioinformatics, Huazhong Agricultural University, Wuhan, Hubei, P.R. China }\end{array}$ \\
\hline 2. & $\begin{array}{l}\text { Stijn Wittouck, Research Group Environmental Ecology and Applied Microbiology, Depart- } \\
\text { ment of Bioscience Engineering, University of Antwerp, Antwerp, Belgium }\end{array}$ \\
\hline 3. & Elisa Salvetti, Department of Biotechnology, University of Verona, Verona, Italy \\
\hline 4. & $\begin{array}{l}\text { Charles M.A.P. Franz, Department of Microbiology and Biotechnology, Max Rubner-Institut, } \\
\text { Kiel, Germany }\end{array}$ \\
\hline 5. & $\begin{array}{l}\text { Hugh M.B. Harris, School of Microbiology and APC Microbiome Ireland, University College } \\
\text { Cork, Cork, Ireland }\end{array}$ \\
\hline 6. & $\begin{array}{l}\text { Paola Mattarelli, Department of Agricultural and Food Sciences, University of Bologna, Bolo- } \\
\text { gna, Italy }\end{array}$ \\
\hline 7. & $\begin{array}{l}\text { Paul W. O'Toole, School of Microbiology and APC Microbiome Ireland, University College } \\
\text { Cork, Cork, Ireland }\end{array}$ \\
\hline 8. & $\begin{array}{l}\text { Bruno Pot, Research Group of Industrial Microbiology and Food Biotechnology (IMDO), Vrije } \\
\text { Universiteit Brussel, Brussels, Belgium }\end{array}$ \\
\hline 9. & $\begin{array}{l}\text { Peter Vandamme, Laboratory of Microbiology, Department of Biochemistry and Microbiology, } \\
\text { Ghent University, Ghent, Belgium }\end{array}$ \\
\hline 10. & $\begin{array}{l}\text { Jens Walter, Department of Agricultural, Food and Nutritional Science, Department of Biologi- } \\
\text { cal Sciences, University of Alberta, Edmonton, Canada }\end{array}$ \\
\hline 11. & $\begin{array}{l}\text { Koichi Watanabe, Department of Animal Science and Technology, National Taiwan Universi- } \\
\text { ty, Taipei, Taiwan R.O.C.; Bioresource Collection and Research Center, Food Industry Re- } \\
\text { search and Development Institute, Hsinchu, Taiwan R.O.C. }\end{array}$ \\
\hline 12. & $\begin{array}{l}\text { Sander Wuyts, Research Group Environmental Ecology and Applied Microbiology, Depart- } \\
\text { ment of Bioscience Engineering, University of Antwerp, Antwerp, Belgium }\end{array}$ \\
\hline 13. & Giovanna E. Felis, Department of Biotechnology, University of Verona, Verona, Italy \\
\hline 14. & $\begin{array}{l}\text { Michael G. Gänzle, Department of Agricultural, Food and Nutritional Science, University of } \\
\text { Alberta, Edmonton, Canada; College of Bioengineering and Food Science, Hubei University of } \\
\text { Technology, Wuhan, Hubei, P.R. China }\end{array}$ \\
\hline 15. & $\begin{array}{l}\text { Sarah Lebeer, Research Group Environmental Ecology and Applied Microbiology, Department } \\
\text { of Bioscience Engineering, University of Antwerp, Antwerp, Belgium }\end{array}$ \\
\hline
\end{tabular}


Znaczenie zmian nomenklatury taksonomicznej Lactobacillus dla konsumentów i producentów żywności

W przeszłości często zmieniały się nazwy pojedynczych gatunków rodzaju Lactobacillus, jednak obecnie blisko 200 gatunków zmieniło nazwę rodzaju podczas jednej operacji. To bezprecedensowa skala zmian, która może powodować dezorientację wśród zainteresowanych stron [20].

Zmiany nazw większości bakterii fermentacji mlekowej bez wątpienia wpłyną zarówno na konsumentów, producentów żywności, na środowiska naukowe, jak i organy ustawodawcze i inspekcje. Konsumenci mogą być zdezorientowani listą składników żywności lub suplementów diety uwzględniającą nową taksonomię bakterii. Etykiety będą musiały zostać zaktualizowane, np. Lacticaseibacillus rhamnosus GG (ATCC 53103), wcześniej sklasyfikowany jako Lactobacillus rhamnosus GG (ATCC 53103). Podobne problemy mogą napotkać naukowcy, a także prawnicy i urzędnicy analizujący stan techniki związany ze zgłoszeniem patentowym. Ważne będzie uwzględnienie nowych nazw w przyszłych publikacjach i nowych zgłoszeniach patentowych, ale kluczowe będzie wyszukiwanie literatury zarówno z poprzednimi, jak i z nowymi nazwami bakterii. Dobra komunikacja będzie kluczem do udokumentowania, że badania kliniczne i publikacje powołujące się na szczep o starej nazwie dotyczą szczepu oznaczonego nowymi nazwami $[14,20]$.

Organy regulacyjne i rządy będą również musiały zaktualizować pozytywne listy bakterii i zapewnić, że same bakterie, ich skuteczność i bezpieczeństwo pozostają niezmienione. EFSA, Health Canada i FDA muszą dostosować swoją literaturę i komunikaty. Co więcej, ustawodawcy są zobowiązani porównać raporty laboratoryjne z listami bezpieczeństwa biologicznego w celu weryfikacji z QPS, GRAS, GMO, dodatkami, IDF lub krajowymi listami [7]. Na przykład w unijnym rejestrze dodatków paszowych ponad $90 \%$ produktów zawiera pałeczki fermentacji mlekowej, co będzie wymagało zmiany nazwy w specyfikacji produktów. Ze względu na wyzwania związane ze zmianą nazw bakterii Lactobacillus, naukowcy zaangażowani w ten projekt opracowali narzędzie internetowe http://lactotax.embl.de/wuyts/lactotax, które ułatwia określenie nowych nazw wszystkich gatunków Lactobacillus [6].

Oficjalne stanowisko w tej sprawie zajął także Europejski Urząd do spraw Bezpieczeństwa Żywności (EFSA). Uznano, że aby zachować ciągłość w ramach listy QPS, wszystkie szczepy należące do wcześniej zdefiniowanego rodzaju Lactobacillus zostaną przeniesione do nowego rodzaju. Zachowane zostaną zarówno poprzednie, jak i nowe nazwy. Na liście QPS znalazło się 37 gatunków, które sklasyfikowano w 13 rodzajach, z których 10 należy teraz do nowego rodzaju Lactobacillus (homonimiczna nazwa poprzedniej nazwy rodzaju), pięć należy do rodzaju Limosilactobacillus, cztery - do Lentilactobacillus, po trzy - do każdego Ligilactobacillus, Lacticaseibacillus 
Tabela 2. Nazwy wybranych gatunków probiotycznych Lactobacillus

Table 2. Names of selected species of probiotic Lactobacillus

\begin{tabular}{|c|c|c|}
\hline $\begin{array}{l}\text { Poprzednia nazwa } \\
\text { Former name }\end{array}$ & $\begin{array}{l}\text { Nowa nazwa } \\
\text { New names }\end{array}$ & $\begin{array}{l}\text { Informacja } \\
\text { Information }\end{array}$ \\
\hline $\begin{array}{l}\text { Lactobacillus delbrueckii } \\
\text { subsp. delbrueckii } \\
\text { Lactobacillus delbrueckii } \\
\text { subsp. bulgaricus } \\
\text { Lactobacillus acidophilus } \\
\text { Lactobacillus crispatus } \\
\text { Lactobacillus gasseri } \\
\text { Lactobacillus helveticus } \\
\text { Lactobacillus iners } \\
\text { Lactobacillus jensenii } \\
\text { Lactobacillus johnsonii }\end{array}$ & $\begin{array}{l}\text { Bez zmian, pozostaje rodzaj } \\
\text { Lactobacillus } \\
\text { No changes, Lactobacillus genus } \\
\text { remains }\end{array}$ & $\begin{array}{l}\text { Są to organizmy przystosowane } \\
\text { do żywiciela, homofermentacyjne } \\
\text { i termofilne } \\
\text { These are host-adapted, homo- } \\
\text { fermentative and thermophilic } \\
\text { organisms }\end{array}$ \\
\hline $\begin{array}{l}\text { Lactobacillus casei } \\
\text { Lactobacillus paracasei } \\
\text { Lactobacillus rhamnosus }\end{array}$ & $\begin{array}{l}\text { Lacticaseibacillus casei } \\
\text { Lacticaseibacillus paracasei } \\
\text { Lacticaseibacillus rhamnosus }\end{array}$ & $\begin{array}{l}\text { Lacti i casei = pozyskiwane } \\
\text { z mleka i skrzepu kazeinowego } \\
\text { Lacti and casei = derived from } \\
\text { milk and casein cheese }\end{array}$ \\
\hline $\begin{array}{l}\text { Lactobacillus sakei } \\
\text { Lactobacillus curvatus }\end{array}$ & $\begin{array}{l}\text { Latilactobacillus sakei } \\
\text { Latilactobacillus curvatus }\end{array}$ & $\begin{array}{l}\text { Latus = szeroki, Latilactobacillus } \\
\text { - szeroko rozpowszechniony } \\
\text { Latus = wide, broad, Latilactoba- } \\
\text { cillus - widespread }\end{array}$ \\
\hline Lactobacillus salivarius & Ligilactobacillus salivarius & $\begin{array}{l}\text { Ligare = łączyć, bakterie łatwo } \\
\text { adaptujące się do żywiciela } \\
\text { Ligare = unite; bacteria that are } \\
\text { easily adaptive to host }\end{array}$ \\
\hline $\begin{array}{l}\text { Lactobacillus plantarum } \\
\text { Lactobacillus pentosus }\end{array}$ & $\begin{array}{l}\text { Lactiplantibacillus plantarum } \\
\text { Lactiplantibacillus pentosus }\end{array}$ & $\begin{array}{l}\text { Lacti, planti = pochodzące } \\
\text { z mleka i produktów roślinnych } \\
\text { Lacti, planti = derived from milk } \\
\text { and plant products }\end{array}$ \\
\hline $\begin{array}{l}\text { Lactobacillus fermentum } \\
\text { Lactobacillus reuteri }\end{array}$ & $\begin{array}{l}\text { Limosilactobacillus fermentum } \\
\text { Limosilactobacillus reuteri }\end{array}$ & $\begin{array}{l}\text { Limosi = śluzowaty, wynikający } \\
\text { ze zdolności szczepów do wytwa- } \\
\text { rzania egzopolisacharydów } \\
\text { Limosi = slimy, resulting from } \\
\text { ability of strains to produce } \\
\text { exopolysaccharides }\end{array}$ \\
\hline Lactobacillus brevis & Levilactobacillus brevis & $\begin{array}{l}\text { Levare = podniesienie, Lactoba- } \\
\text { cillus z potencjałem zakwaszania } \\
\text { Levare = uplift, Lactobacillus } \\
\text { with acidification potential }\end{array}$ \\
\hline $\begin{array}{l}\text { Lactobacillus buchneri } \\
\text { Lactobacillus kefiri }\end{array}$ & $\begin{array}{l}\text { Lentilactobacillus buchneri } \\
\text { Lentilactobacillus kefiri }\end{array}$ & $\begin{array}{l}\text { Lentus = powolny, odnoszący się } \\
\text { do powolnego wzrostu z mlecza- } \\
\text { nem lub propanodiolem jako } \\
\text { źródłem węgla } \\
\text { Lentus = slow, referring to slow } \\
\text { growth with lactate or propanediol } \\
\text { as source of carbon }\end{array}$ \\
\hline
\end{tabular}

Źródło / Source: opracowanie własne na podstawie [22] / the author’s own study based on [22] 
i Lactiplantibacillus, po dwa - do Companilactobacillus i Latilactobacillus oraz po jednym - do każdego z rodzajów Levilactobacillus, Secundilactobacillus, Loigolactobacillus, Fructilactobacillus i Lapidilactobacillus [4].

Eksperci z IPA (International Probiotic Association in Europe) oraz ISAPP (International Scientific Association for Probiotics and Prebiotics) opracowali naukowe kryteria, aby zapewnić prawidłowe stosowanie terminu probiotyk. Kluczowym elementem prawidłowej charakterystyki probiotyków jest właściwa identyfikacja i nazewnictwo szczepu. Stwierdzono, że ,złotym standardem” identyfikacji bakterii probiotycznych jest sekwencjonowanie całego genomu, w tym wszelkich elementów pozachromosomalnych. Ponadto szczepy probiotyczne należy nazywać zgodnie z aktualnie obowiązującą nomenklaturą bakteryjną, bazującą na Międzynarodowym Kodeksie Nomenklatury [10]. Zaktualizowana lista nazw prokariotycznych występujących w nomenklaturze jest dostępna pod adresem http://www.bacterio.net [12].

Należy jednak podkreślić, że chociaż rodzaj i nazwa gatunku określonego szczepu mogą ulec zmianie, oficjalne oznaczenie szczepu (numer szczepu znany w jednej lub większej liczbie kolekcji kultur referencyjnych) pozostanie bez zmian, ponieważ procedura zmiany nazwy obejmuje tylko nazwę rodzaju Lactobacillus [1].

Pod względem naukowym rezultatem wydzielenia nowych grup taksonomicznych jest bliższe spokrewnienie gatunków zaklasyfikowanych do nowego rodzaju. Istnieje zatem większe prawdopodobieństwo, że mają one wspólne cechy fizjologiczne. Może to ułatwić zrozumienie wspólnych mechanizmów, które decydują o korzyściach zdrowotnych. Na przykład bakterie przystosowane do żywiciela są bardziej konkurencyjne w porównaniu z bakteriami, które nie mają wspólnej historii ewolucyjnej z gospodarzem, co może być interesujące przy opracowywaniu produktu mającego na celu antagonizm w stosunku do patogenów. Bakterie niepołączone ewolucyjnie z żywicielem będą natomiast potencjalnie słabiej tolerowane przez organizm człowieka lub zwierząt i bardziej skłonne do indukowania odpowiedzi immunologicznej, co może być ważne przy opracowywaniu produktów wspomagających odporność $[3,9,18]$.

\section{Podsumowanie}

Pełne przejście od starej do nowej nomenklatury bakterii z rodzaju Lactobacillus będzie procesem żmudnym i długotrwałym. Obecnie wszystkie zainteresowane strony muszą przyzwyczaić się do nowych nazw pojawiających się na etykietach żywności i suplementów diety, a naukowcy i ustawodawcy - dołożyć starań, aby używać nowych, poprawnych nazw. Podobne narastające problemy z porządkiem nomenklatury taksonomicznej obserwuje się w rodzaju Bifidobacterium. Jak dotąd nazewnictwo bakterii z tej grupy nie zmieniło się, ale wkrótce można spodziewać się także w tym przypadku zmiany nomenklatury. 
Chociaż wszystkie te kwestie mogą wydawać się dość niepokojące, w rezultacie zaproponowane zmiany wprowadzają szereg korzyści. Należą do nich:

- zgrupowanie blisko spokrewnionych bakterii w bardziej jednolite i stabilne ewolucyjnie taksony,

- stworzenie możliwości zdefiniowania dokładniejszych markerów molekularnych, które ułatwią identyfikację i przyczynią się do lepszego poznania i zrozumienia specyfiki nowych grup bakterii,

- pozytywny wpływ na projektowanie ukierunkowanych grup żywności, cechujących się funkcjonalnością i skutecznością prozdrowotną.

Praca finansowana przez Ministerstwo Nauki i Szkolnictwa Wyższego w ramach środków na utrzymanie potencjału badawczego Instytutu Nauk o Żywieniu Człowieka, SGGW w Warszawie.

\section{Literatura}

[1] Binda S., Hill C., Johansen E., Obis D., Pot B., Sanders M.E., Tremblay A., Ouwehand, A.C.: Criteria to qualify microorganisms as "Probiotic" in foods and dietary supplements. Front. Microbiol., 2020, 11, \#1662.

[2] Collins M.D., Rodrigues I.I., Ash C., Aguirre M., Farrow J.A.E., Martinez-Murcia A., Phillips B.A., Williams A.M., Wallbanks S.: Phylogenetic analysis of the genus Lactobacillus and related lactic acid bacteria as determined by reverse transcriptase sequencing of 16S rRNA. FEMS Microbiol. Lett., 1991, 77 (1), 5-12.

[3] Duar R.M., Lin X.B., Zheng J., Martino M.E., Grenier T., Pérez-Muñoz M.E., Leulier F., Gänzle M., Walter J.: Lifestyles in transition: Evolution and natural history of the genus Lactobacillus. FEMS Microbiol Rev. 2017, 1 (41), 27-48.

[4] EFSA Panel on Biological Hazards (BIOHAZ): Update of the list of QPS-recommended biological agents intentionally added to food or feed as notified to EFSA 12: Suitability of taxonomic units notified to EFSA until March 2020. EFSA J., 2020, 18 (7), \#6174.

[5] Felis G.E., Dellaglio F.: Taxonomy of lactobacilli and bifidobacteria. Curr. Issues Intest. Microbiol., 2007, 8 (2), 44-61.

[6] Baza Lactotax. [on line]. Dostęp w Internecie [25.08.2020]: http://lactotax.embl.de/wuyts/lactotax

[7] Laulund S., Wind A., Derkx P.M., Zuliani V.: Regulatory and safety requirements for food cultures. Microorganisms, 2017, 5 (2), \#28.

[8] Markets and Markets: Probiotics market by application (functional food \& beverages [dairy products, non-dairy beverages, infant formula, cereals], dietary supplements, feed), ingredient (bacteria, yeast), form (dry, liquid), end user, and region - global forecast to 2023. [on line]. Dostęp w Internecie [25.08.2020]: https://www.marketsandmarkets.com/Market-Reports/probiotic-market-advancedtechnologies-and-global-market-69.html

[9] Pane M., Vinot N.: The Lactobacillus taxonomy change is coming: Why, and how to make the most of it? [on line]. Dostęp w Internecie [25.08.2020]: https://www.microbiometimes.com/thelactobacillus-taxonomy-change-is-coming-why-and-how-to-make-the-most-of-it

[10] Parker C.T., Tindall B.J., Garrity G.M.: International code of nomenclature of Prokaryotes. Int. J. Syst. Evol. Microbiol., 2019, 69(1A), 1-111. 
[11] Parks D.H., Chuvochina M., Chaumeil P.A., Rinke C., Mussig A.J., Hugenholtz P.: A complete domain-to-species taxonomy for Bacteria and Archaea. Nature Biotechnol., 2020, 38, 1079-1086.

[12] Parte A.C.: LPSN - List of prokaryotic names with standing in nomenclature (bacterio.net), 20 years on. Int. J. Syst. Evol. Microbiol., 2018, 68, 1825-1829.

[13] Pot B., Felis G.E., De Bruyne K., Tsakalidou E., Papadimitriou K., Leisner J., Vandamme P.: The genus Lactobacillus. In: Lactic Acid Bacteria: Biodiversity and Taxonomy. Eds. W. H. Holzapfel, B.J.B. Wood. Wiley-Blackwell, 2014, pp. 249-353.

[14] Pot B., Salvetti E., Mattarelli P., Felis G.E.: The potential impact of the Lactobacillus name change: The results of an expert meeting organised by the Lactic Acid Bacteria Industrial Platform (LABIP). Trends Food Sci. Technol., 2019, 94, 105-113.

[15] Lloyd Ch.: What on Earth Evolved? 100 Species That Changed the World. Bloomsbury Publishing, London 2009

[16] Salvetti E., Harris H.M.B., Felis G.E., O’Toole P.W.: Comparative genomics of the genus Lactobacillus reveals robust phylogroups that provide the basis for reclassification. Appl. Environ. Microbiol., 2018, 84 (17), \#00993-18.

[17] Salvetti E., Torriani S., Felis G.E.: The genus Lactobacillus: A taxonomic update. Probiotics Antimicrob. Proteins, 2012, 4 (4), 217-226.

[18] Sanders M.E., Benson A., Lebeer S., Merenstei D.J., Klaenhammer T.R.: Shared mechanisms among probiotic taxa: Implications for general probiotic claims. Curr. Opin. Biotechnol., 2018, 49, 207-216.

[19] Sun Z., Harris H.M.B., McCann A., Guo C., Argimón S., Zhang W., Yang X., Jeffery I.B., Cooney J.C., Kagawa T.F., Liu W., Song Y., Salvetti E., Wrobel A., Rasinkangas P., Parkhill J., Rea M.C., O'Sullivan O., Ritari J., Douillard F.P., Paul Ross R., Yang R., Briner A.E., Felis G.E., de Vos W.M., Barrangou R., Klaenhammer T.R., Caufield P.W., Cui Y., Zhang H., O'Toole P.W.: Expanding the biotechnology potential of lactobacilli through comparative genomics of 213 strains and associated genera. Nat. Commun., 2015, 6 (1), 1-13.

[20] Vinot N., Pane M.: The Lactobacillus taxonomy change has arrived! What do you need to know? [on line]. Dostęp w Internecie [25.08.2020]: https://www.microbiometimes.com/the-lactobacillustaxonomy-change-has-arrived-what-do-you-need-to-know

[21] Zheng J., Ruan L., Sun M., Gänzle M.A.: Genomic view of lactobacilli and pediococci demonstrates that phylogeny matches ecology and physiology. Appl. Environ. Microbiol., 2015, 81 (20), 72337243.

[22] Zheng J., Wittouck S., Salvetti E., Franz Ch.M.A.P., Harris H., Mattarell P., O’Toole P.W., Pot B., Vandamme P., Walter J., Watanabe K., Wuyts S., Felis G.E., Gänzle M.G., Lebeer S.: A taxonomic note on the genus Lactobacillus: Description of 23 novel genera, emended description of the genus Lactobacillus Beijerinck 1901, and union of Lactobacillaceae and Leuconostocaceae. Int. J. Syst. Evol. Microbiol., 2020, 70 (4). DOI: 10.1099/ijsem.0.004107.

[23] Zielińska D., Sionek B., Kołożyn-Krajewska D.: Safety of probiotics. In: Diet, Microbiome and Health. Eds. A. Grumezescu, A.M. Holban. Academic Press, London 2018, pp. 131-161.

\title{
CHANGES OF THE TAXONOMIC NOMENCLATURE OF IMPORTANT SPECIES OF PROBIOTIC LACTOBACILLUS BACTERIA
}

\author{
$\mathrm{S} u \mathrm{~mm}$ a r y
}

From their key role in food fermentation to their beneficial effects on human and animal bodies, Lactobacillus species are of great importance in human life The objective of this paper was to present a cur- 
rent revolutionary change in taxonomic nomenclature with reference to the history of Lactobacillus genus, and to discuss the impact of that change on consumers, probiotic food producers, and other interested parties. Fifteen scientists from twelve different institutions and seven different countries analyzed the entire genome of every known Lactobacillus species and suggested changes. Their proposition was accepted for publication in the official journal of bacterial name registers. The authors assumed a multiphase approach in their analyses and on this basis they reclassified the Lactobacillus genus into 25 types. This unprecedented scale of changes can be confusing to the interested. However it also has a number of benefits associated with grouping closely related bacteria into more uniform and evolutionarily stable taxa and also with creating a possibility to better design targeted food groups characterised by functionality and biological effectiveness.

Key words: Lactobacillus, probiotics, taxonomy, genus 